\title{
Seasonal Variation in Growth, Leaf Physiology and Fruit Development in Kinnow, a Mandarin Hybrid
}

\author{
R. P. S. Dalal ${ }^{1}$, B. S. Beniwal ${ }^{1} \&$ S. K. Sehrawat ${ }^{1}$ \\ ${ }^{1}$ Department of Horticulture, CCS Haryana Agricultural University, India \\ Correspondence: R. P. S. Dalal, Department of Horticulture, CCS Haryana Agricultural University, India. E-mail: \\ dala108@rediffmail.com
}

Received: September 20, 2012 Accepted: November 25, 2012 Online Published: December 5, 2012

doi:10.5539/jps.v2n1p72

URL: http://dx.doi.org/10.5539/jps.v2n1p72

\begin{abstract}
In the early bearing stage of Kinnow, the magnitude of vegetative growth was maximum in spring flush (47.08\%) followed by in the rainy season flush $(42.07 \%)$, whereas, the winter fall flush bore only minor flush of the annual vegetative growth $(10.85 \%)$. Similarly, the spring flush leaves showed the minimum values of leaf sclerophylly i.e. leaf area, leaf fresh and dry weight, specific leaf weight, density of foliar tissue and leaf tissue succulency as compared to rainy and winter fall flushes leaves, implying that spring season growth most serves as a sink to developing fruits. Growth of the Kinnow fruit in phase $1^{\text {st }}$ which last for one month up to April is primarily due to the increase in peel thickness which contributes about $70 \%$ of the fruit radius. In phase $2^{\text {nd }}$, growth of the fruit is due to the increase in pulp tissue thickness contributing $80 \%$ of the fruit radius, increased fruit fresh weight, moisture content and decreased peel thickness up to September. Major gain in fresh weight of the fruit is from May-October, contributing $80.14 \%$ of the total fruit weight. Thereafter, phase $3^{\text {rd }}$ of maturation and ripening starts with comparatively decreased rate of increase in fruit weight and size, and slightly increased rate of dry weight, peel thickness and reduced moisture percentage. This study will be further helpful in increasing the input efficiency of resources for improving fruit size and reducing fruit drop in Kinnow mandarin.
\end{abstract}

Keywords: Kinnow, seasonal variation, growth magnitude, leaf sclerophylly, fruit development

\section{Introduction}

Full grown citrus trees in commercial orchard in northern India tend to produce growth flushes at about the same time each year. These growth flushes refer to spring (February-March); rainy season (July-August) and fall flushes (October-November). Flowering takes place during spring season. Stage of growth and fruit development phenology is important in formulating plant protection measures and fertilizers scheduling. Earliness and lateness of growth flushes and differences in quantity of new growth are subject for frequent comment by growers. Measurement of foliage growth as to either time or quantity, seldom appear in earlier published work and those that are available usually pertains to green house observations on young trees in connection with nutritional studies. Such data have not heretofore been available. Simanton (1970) reported that spring flush comprised 59\% of the annual growth in citrus, whereas, fall growth was usually minor and erratic. Similarly, Bower (2007) observed that spring flush (March-April in northern hemisphere) is usually far more intense, affecting more growing points than the summer flush. Differences are mostly attributed to temperature and soil moisture immediately preceding or during the flush period and crop load. In the mature plants loaded with heavy crop, the rainy season flush is either missed or minor due to competition for sink by vegetative and reproductive growth. Hence, the importance of adequate foliage to yield and quality of fruit crop is widely recognized. Goldschmidt and Koch (1996) reported that in fully expanded leaves starch and soluble sugar levels decline and stay low during summer and autumn, because of heavy demand of developing fruits. Iglesias et al. (2007) reported that regulation of fruit growth and development in citrus is an intricate phenomenon depending upon many internal and external factors that may operate both sequentially and simultaneously. The cell enlargement phase varies with cultivar and climate, but typically three to four months (Davies \& Albrigo, 1994). If growth pattern of the tree is taken into account and linked with the known constituent and perceived activity of applied compounds, then the optimal timing for desired effect can be determined. Little has been done to outline the vegetative and fruit growth within any major production area, with the exception of the fruit maturity rate in citrus, which can vary considerably with cultivar and environmental conditions. An understanding of growth 
pattern, magnitude and fruit development stages has been useful in Kinnow for making management decisions. So, the present study was undertaken with the objective to present quantitative data on the relative amount of new foliar growth during different flushes season and fruit growth pattern of Kinnow, which further help in attaining particular desired effect in matching the input application.

\section{Material and Methods}

\subsection{Experimental Site and Plant Material}

The experiment was conducted during the years 2010 and 2011 at the experimental orchard of the Department of Horticulture, CCS HAU, Hisar, India, located at $29^{\circ} 10^{\prime}$ longitudes; $75^{\circ} 46^{\prime}$ latitude and at altitude of $215.2 \mathrm{~m}$ amsl with average annual rainfall $350 \mathrm{~mm}$. Rainfall mostly takes place through the south-western monsoon during July-August. The maximum temperature goes up to $45^{\circ} \mathrm{C}$ during summer in May-June and minimum to even zero degree during winter months (December-January). The soil of the experimental orchard was low in organic carbon $(0.42 \%)$ and nitrogen $(87 \mathrm{~kg} / \mathrm{ha})$, medium in phosphorus $(12 \mathrm{~kg} / \mathrm{ha})$ and high in potash content $(384 \mathrm{~kg} / \mathrm{ha})$. The experiment was conducted on six- years- old Kinnow plants budded on rough lemon rootstock and planted at $6 \times 6 \mathrm{~m}$ spacing under uniform cultural practices.

\subsection{Data Collection}

\subsubsection{Growth Parameters}

The active vegetative growth cycle was divided into three flushes i.e. spring flush (February-March); rainy season flush (July-August) and winter fall (October-November). The magnitude of flush growth and trunk diameter was measured for these three seasons during 2010. The flush growth of the respective season after cessation of growth was measured from the trees and fresh weight was weighed with top pan balance. The diameter of the trunk was measured $6 \mathrm{~cm}$ above bud union during mid of January, April, September and mid January in the next year and trunk growth rate/ season was measured by calculating the differences in between for the spring, rainy and winter fall season, respectively.

\subsubsection{Leaf Physiological Parameters}

Ten mature leaves, two and half month old per replication were collected from each tree from each season flush and following leaf parameters were examined; leaf area (LA) using leaf area meter (Make AM 300 Area Meter: Bioscientific Ltd. Hoddesdon, UK), leaf fresh weight (FW) and dry weight (DW) per leaf during 2010. The leaves were weighed immediately after harvest to determine their fresh weight. Then these leaves were oven dried at $70^{\circ} \mathrm{C}$ for 48 hours and their dry weight was then determined. Several indices of leaf physiological parameters were calculated by the formulas suggested by Ennajeh et al. (2010); Specific leaf area (SLA= LA/ DW: in $\mathrm{cm}^{2} \mathrm{~g}^{-1} \mathrm{DW}$ ), specific leaf weight ( $\mathrm{SLW}=\mathrm{DW} / \mathrm{LA}$ : in $\mathrm{g} \mathrm{cm}^{2} \mathrm{LA}$ ), density of foliar tissue ( $\mathrm{D}=\mathrm{DW} / \mathrm{FW} \mathrm{X}$ 1000: in $\mathrm{g} \mathrm{kg}^{-1}$ ) and succulency [S=(FW-DW)/LA: in $\mathrm{mg} \mathrm{H}_{2} \mathrm{O} \mathrm{cm}^{-2}$ ]. The experiment was laid out in completely randomized design with seven replications taking single plant as one unit.

\subsubsection{Fruit Development Parameters}

Fruit growth in terms of fruit diameter, peel and pulp thickness, fruit fresh weight, fruit dry weight, moisture content was measured from $30^{\text {th }}$ April onwards at monthly interval up to December during the years 2010 and 2011 and data was averaged for these two years. Fruit diameter was measured by tagging fruits on four plants i.e. four fruits on each plant in all the directions on the plant and the same fruits were used every month for measuring diameter. Sixteen fruits were harvested on each date of observation and weighed with electronic balance. These fruits were cut into two halves and fruit peel and pulp thicknesses were measured at the equatorial region with the help of vernier caliper. Subsequently, fruits were cut in small pieces and oven dried at $48^{\circ} \mathrm{C}$ temperature till the constant weight. Moisture content was calculated by subtracting the dried weight from the fresh weight and percentage moisture content was worked out on fresh weight basis. Fruit growth data was collected for two year and averaged.

\subsection{Layout and Statistical Analysis}

Uniform plants were selected on stem diameter and canopy volume basis from a block of Kinnow plantation under uniform cultural practices as per the package of practices for fruit crops of the state. For growth and leaf physiological parameters, the treatments were replicated seven times by taking single plant as one unit. The data for the above parameters was analyzed statistically in a Completely Randomized Design and their means were compared with critical differences at $5 \%$ level of significance. 


\section{Results and Discussion}

\subsection{Growth Parameters}

Among different flushes, the magnitude of vegetative flush and trunk growth rate differed significantly in the early bearing stage (Table 1). On fresh weight basis, the magnitude of spring flush was found to be significantly highest $(4.77 \mathrm{~kg} / \mathrm{plant})$, followed by rainy season flush $(4.25 \mathrm{~kg} / \mathrm{plant})$ and winter fall flush $(1.10 \mathrm{~kg} / \mathrm{plant})$. The contribution of spring flush, rainy season flush and winter fall flush was $47.08 \%, 42.07 \%$ and $10.85 \%$ respectively of the annual growth. Simanton (1970) reported similar results that spring flush comprise $59 \%$ of the annual growth, whereas, fall growth was usually minor and erratic. Trunk growth rate was influenced significantly during the different seasons (Table1). However, the maximum trunk growth rate was measured in the spring season $(0.587 \mathrm{~cm})$ closely followed by in rainy season $(0.551 \mathrm{~cm})$ and significantly lowest growth rate was measured in the winter fall season $(0.404 \mathrm{~cm})$. The spring flush in northern hemisphere is usually more intense, effecting more growing points than the summer flush (Bower, 2007).

Table 1. Seasonal variation in the vegetative growth of Kinnow mandarin

\begin{tabular}{llll}
\hline Seasons & $\begin{array}{l}\text { Fresh weight of growth/ } \\
\text { plant }(\mathrm{kg})\end{array}$ & $\begin{array}{l}\text { Growth on fresh weight } \\
\text { basis }(\%)\end{array}$ & $\begin{array}{l}\text { Trunk growth rate } \\
\text { (increase in } \\
\text { diameter cm/ season) }\end{array}$ \\
\hline Spring season & 4.77 & 47.08 & 0.587 \\
Rainy season & 4.25 & 42.07 & 0.551 \\
Winter fall & 1.10 & 10.85 & 0.404 \\
CD at 5\% & 0.29 & 2.55 & 0.120 \\
\hline
\end{tabular}

Table 2. Seasonal variation in the leaf sclerophylly in Kinnow mandarin

\begin{tabular}{llllllll}
\hline Seasons & $\begin{array}{l}\text { Leaf area } \\
\left(\mathrm{cm}^{2} / \text { leaf }\right)\end{array}$ & $\begin{array}{l}\text { Leaf } \\
\text { fresh } \\
\text { weight } \\
(\mathrm{g})\end{array}$ & $\begin{array}{l}\text { Leaf dry } \\
\text { weight }(\mathrm{g})\end{array}$ & $\begin{array}{l}\text { Specific } \\
\text { leaf area } \\
\left(\mathrm{cm}^{2} / \mathrm{g}\right)\end{array}$ & $\begin{array}{l}\text { Specific } \\
\text { leaf weight } \\
\left(\mathrm{g} / \mathrm{cm}^{2}\right)\end{array}$ & $\begin{array}{l}\text { Density of } \\
\text { foliar } \\
\text { tissue } \\
(\mathrm{g} / \mathrm{kg})\end{array}$ & $\begin{array}{l}\text { Succulency } \\
\left(\mathrm{mg} \mathrm{H}_{2} \mathrm{O} / \mathrm{cm}^{2}\right)\end{array}$ \\
\hline Spring season & 14.45 & 0.320 & 0.124 & 116.58 & 0.009 & 37.89 & 0.014 \\
Rainy season & 15.79 & 0.448 & 0.170 & 93.10 & 0.011 & 38.69 & 0.018 \\
Winter fall & 14.45 & 0.425 & 0.193 & 75.32 & 0.013 & 45.46 & 0.016 \\
CD at 5\% & 0.59 & 0.027 & 0.011 & 5.88 & 0.001 & 1.84 & 0.001 \\
\hline
\end{tabular}

\subsection{Leaf physiological Parameters}

Leaf physiological parameters differed significantly among various growth flushes (Table 2). Rainy season flush leaves showed the maximum leaf area $\left(15.79 \mathrm{~cm}^{2} /\right.$ leaf $)$, fresh leaf weight $(0.448 \mathrm{~g} /$ leaf $)$ and leaf succulency $\left(0.018 \mathrm{mg} \mathrm{H}_{2} \mathrm{O} / \mathrm{cm}^{2}\right)$ which were also significantly higher over spring and winter flush leaves. This may be due to the better availability of soil moisture and high relative humidity resulting in low transpirational losses, which favours the better leaf growth in terms of leaf area, leaf weight and succulency during rainy season. The minimum leaf area $\left(14.45 \mathrm{~cm}^{2} /\right.$ leaf), fresh leaf weight $(0.320 \mathrm{~g} /$ leaf $)$ and succulency $\left(0.014 \mathrm{mgH}_{2} \mathrm{O} / \mathrm{cm}^{2}\right)$ was measured from spring flush leavers, which were also significantly more than the winter flush. This may be due to higher summer temperatures at sampling time resulting in rapid transpirational losses, hence decreased leaf area, leaf weight and succulency. Winter season flush leaves showed the significantly highest leaf dry weight $(0.320 \mathrm{~g} / \mathrm{leaf})$, specific leaf weight $\left(0.013 \mathrm{~g} / \mathrm{cm}^{2}\right)$, and density of foliar tissue $\left(45.46 \mathrm{~g} / \mathrm{kg}^{-1}\right)$. This may be because soluble sugars increased towards mid winter in cool areas, as an osmotic, cryoprotective measure against cold injury (Torikata et al., 1974). However, the minimum leaf dry weight $(0.124 \mathrm{~g} / \mathrm{leaf})$, specific leaf weight $\left(0.009 \mathrm{~g} / \mathrm{cm}^{2}\right)$ and density of foliar tissue $\left(37.89 \mathrm{~g} / \mathrm{kg}^{-1}\right)$ were observed in the spring flush leaves. Low dry weight in spring flush leaves indicates that reserve carbohydrates are utilized to sustain the early stage of reproductive development. It is evident from the present investigation that rate of increase in dry weight of fruit is more in the early stages whereas only minor increase was noticed during rainy season. Mehouachi et al. (1995) reported that developing fruits are utilizing sinks during cell division period and act rather as storage sink during phase 11 
(cell enlargement period). Similar results were earlier observed by Shimizu et al. (1978) and Akao et al. (1981) who reported that reserve carbohydrates in spring flush leaves were utilized mainly to support the reproductive development; while old leaves photosynthesis supplied the need of vegetative growth. The maximum specific leaf area was found in spring season flush $\left(116.58 \mathrm{~cm}^{2} / \mathrm{g}\right)$ which was significantly higher over the rainy season flush $\left(75.32 \mathrm{~cm}^{2} / \mathrm{g}\right)$. High specific leaf area may be due to decrease density of foliar tissue of spring season flush.

\subsection{Fruit Development Parameters}

Monthly fruit growth was taken as fruit fresh weight, dry weight, moisture content, fruit diameter, peel and pulp thickness (Figures 1 and 2). The diameter of the fruit increased at faster rate up to August then increase was comparatively low up to harvest. Peel thickness was maximum in the initial stage in the month of April, which contribute about approximately three fourth of the fruit radius $(70.2 \%)$, while contribution in May decreased which was to the tune of $38.5 \%$. In the month of June, there was a drastic reduction in peel thickness $(23.10 \%)$, thereafter, the rate of reduction in peel thickness was comparative low and it reaches to minimum thickness in September $(2.67 \mathrm{~mm})$, followed by increase in peel thickness. Pulp tissue contribute only $29.8 \%$ of the fruit radius in the month of April thereafter, a very fast increase in the pulp tissue growth in the month of May and June was observed which contributed 61.5 and $77.04 \%$ respectively of the fruit radius, subsequently, the pulp tissue increased with decreasing rate continuously up to harvest, but with a very slow rate after September onwards. So, just after fruit set in March in Kinnow, initially for one month increase in diameter of fruit is due to increase in peel thickness and thereafter, increase in fruit size was due to increased pulp tissue. This may be due to the cell division at initial stages mainly due to the peel tissue thickness. Decrease in peel tissue thickness from May onwards may be due to the increased growth of the pulp tissue which stretched the peel tissue. It is hypothesized that fruit growth initially is due to cell division and during May to September there is cell enlargement stage followed by slow rate of growth i.e. maturation and ripening stage. Similarly, Bain (1958) reported that increased fruit size during stage 1 was mainly due to growth of peel and peel has two-third of fruit radius at the end of stage 1 . The increase in peel thickness was due to increased cell division in ovary wall. Again, Altaf and Khan (2009) found that diameter of Kinnow fruit increased at faster rate up to August and then slowed down comparatively. After cessation of cell division, fruit cell differentiation takes place, followed by a period of cell enlargement, enhances pulp growth resulting in large size fruit (Augusti, 2000). The growth in the pulp may also be attributed to cell expansion of the juice vesicles (Augusti et al., 1995).

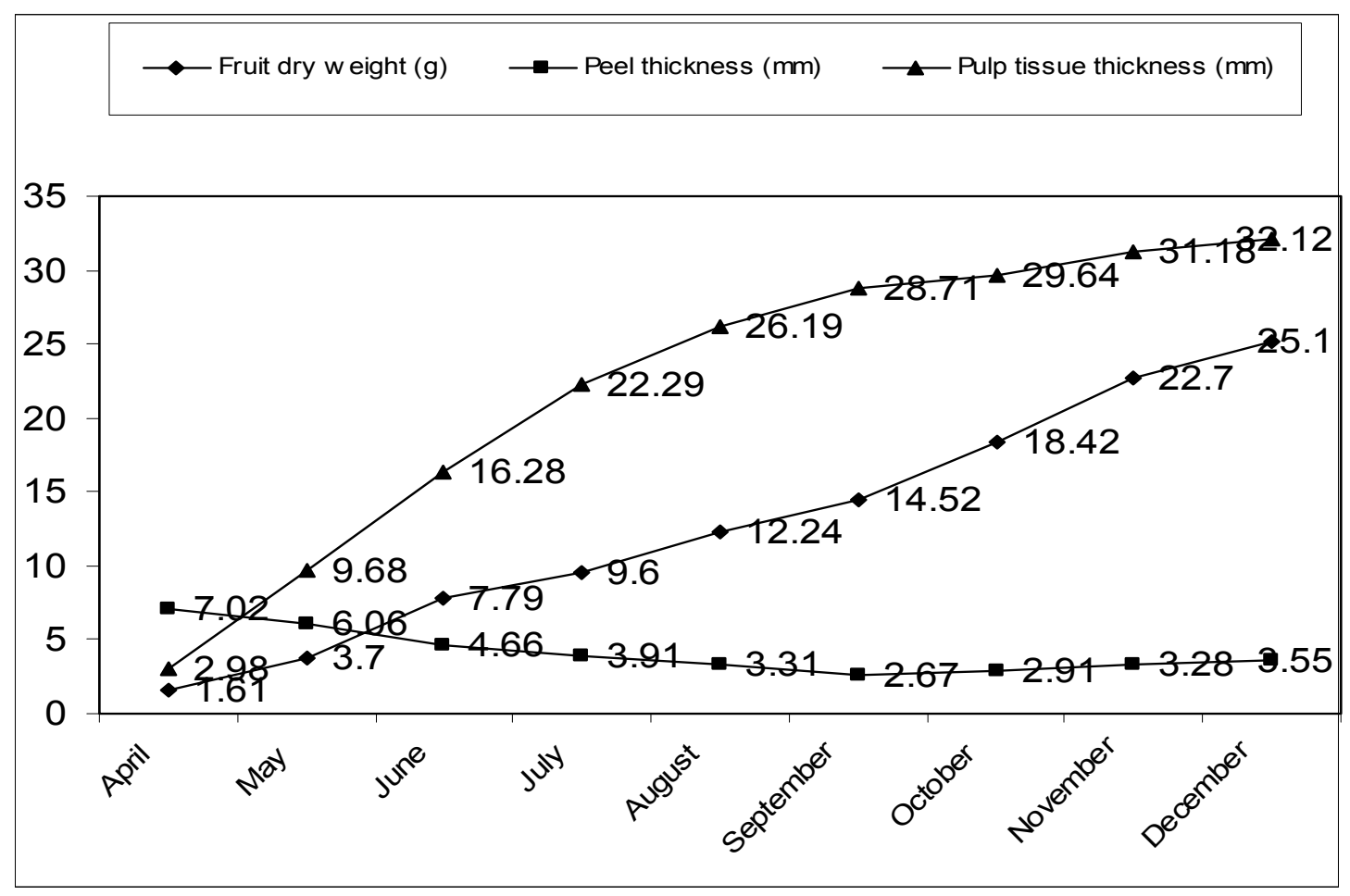

Figure 1. Monthly increment in the fruit dry weight, peel thickness and pulp tissue thickness in the developing Kinnow fruit. (Average data of 2010 and 2011) 


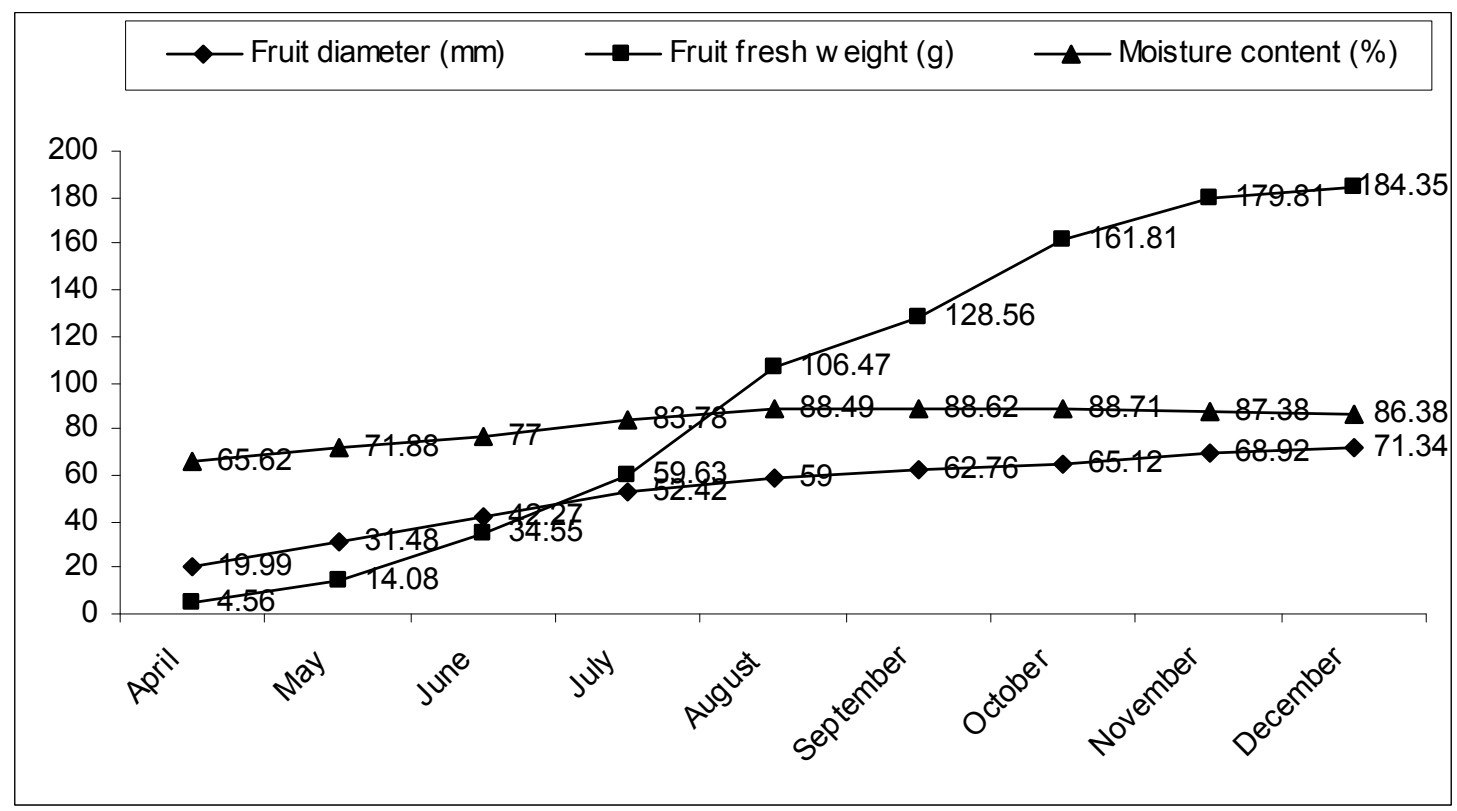

Figure 2. Monthly increment in the fruit diameter, fruit fresh weight and moisture content in the developing Kinnow fruit (Average data of 2010 and 2011)

Fresh weight and dry weight of the fruit increased continuously up to harvest. The fresh weight increased more rapidly from May onwards to October contributing more than three fourth of the total weight $(80.14 \%)$. Subsequently, October onwards the fruit weight increased slowly. Dry weight increased at fast rate up to June, followed by slow increase in July, August and September thereafter, rate of increase in dry weight was comparatively more up to harvest. Moisture content of the fruit increased continuously up to August, followed by minor change up to October and then decreasing trend was observed. Increased fruit weight was due to increase in pulp tissue (juice sacs enlargement) and increase juice content in pulp tissue coinciding with the onset of monsoon rain in July in the region, hence increased fruit weight and moisture content. It was observed that from October onward dry weight increased with decreased moisture content. This results due to accumulation of more sink during this period which is again indicated by more fruit drop during this period. It seems that transition phase takes place from stage 11(cell enlargement stage) to stage 111(maturation and ripening stage) in the month of October with change in colour from green to yellow. These results are corroborated with the finding of Bain (1958) in Valencia orange, who reported that growth and development of citrus fruit follows a typical sigmoid growth curve, divided in to three clear-cut stages. The initial phase or phase 1 , is an approximately two month interval of cell division and slow growth including the period between anthesis and June drop. Therefore, in the rapid growth period (phase 11) fruit experiences a huge increase in size by cell enlargement and water accumulation during four to six months. Finally, in phase 111 or ripening period, growth is mostly arrested and fruit undergo a non-climacteric process. Altaf and Khan (2009) found that the Kinnow fruit gain maximum weight during August-October and there was a slight comparative increase until February. Similarly, Bower (2007) observed that citrus has a sigmoidal growth pattern. The first phase is one of cell division which takes approximately six weeks followed by a second as cell division being decreasing. This probably related to plant growth regulator changes. Davies and Albrigo (1994) reported that cell enlargement phase varies with cultivar and climate, but typically three to four months. Thereafter, maturation occurs which is characterized by decreased juice acid, small increase in sugar and change in rind colour.

It may be concluded that in early bearing stage of Kinnow, spring and rainy season flushes contributed the major vegetative growth. Spring flush leaves showed the lowest values for leaf physiological parameters (LA, FW, DW, SLW, density of foliar tissue and leaf succulency) compared to rainy and winter fall flushes. This indicates that spring season flush serves as a major sink for the developing fruits. Kinnow fruit showed a sigmoidal growth pattern. The fruit growth may be divided in to three phases. The phase $1^{\text {st }}$ (cell division) is for about one month just after fruit set with increased peel thickness followed by phase $2^{\text {nd }}$ with increased pulp thickness, fruit fresh weight and moisture content and decreased peel thickness for about 5-6 months (cell enlargement), subsequently, 
the phase $3^{\text {rd }}$ with reduced rate of fruit growth and change in fruit colour (maturation and ripening satge).

\section{References}

Akao, S., Tsukahara, S., Hisada, H., \& Ono, S. (1981). Contribution of photosynthetic assimilates to development of flower and spring flush in Citrus unshiu Marc. J. Jpn. Soc. Hort. Sci., 50, 1-9. http://dx.doi.org/10.2503/jjshs.50.1

Altaf, N., \& Khan, A. R. (2009). Growth and development of low seeded kinnow mandarin fruits in dense plantation. J. Agric. Sci. Technol., 11, 191-198.

Augusti, M. (2000). Regulation of citrus cropping and improvement of fruit quality using exogenous plant growth regulators. Proc. Intl. Soc. Citriculture, 9, 351-356.

Augusti, M., El-Otmani, M., Aznar, M., Juan, M., \& Almela, M. (1995). Effect of 3,5,6 trichloro-2-pyridyloxyacetic acid on fruit size at maturity. J. Hort. Sci., 70, 855-862.

Bain, J. M. (1958). Morphological, anatomical and physiological changes in developing fruits of the Valencia Orange (Citrus sinensis (L.) Osbeck). Australian J. Bot., 6, 1-25. http://dx.doi.org/10.1071/BT9580001

Bower, J. P. (2007). The pre-and post harvest application potential for crop- set TM and ISR2000TM on citrus. http://en.engormix.com/MA-agriculture/articles/th-pre

Davies, F. S., \& Albrigo, L. G. (1994). Citrus crop production science in Agriculture. CAB International: Wallingford.

Ennajeh, M., Vadel, A. M., Cochard, H., \& Khemira, H. (2010). Comparative impacts of water stress on the leaf anatomy of a drought resistant and a drought sensitive olive cultivar. J. Hort. Sci. Biotech., 85, 289-294.

Goldschmidt, E. E., \& Koch, K. E. (1996). Citrus In: Photoassimilate distribution on plants and crops. Zamski, E., \& Schaffer, A. A. (Eds.). Marcel Dekker Inc. New York, pp. 797-823.

Iglesias, D. J., Cercos, M., Jose, M. C. F., Naranjo, M. A., Rios, G., Carrera, E., Talon, M. (2007). Physiology of $\begin{array}{lllll}\text { citrus fruiting. Braz. J. Plant } & \text { Physiol., }\end{array}$ http://dx.doi.org/10.1590/S1677-04202007000400006

Mehouachi, J., Serna, D., Zaragoza, S., Augusti, M., \& Primo-Millo, E. (1995). Defoliation increases fruit abscission and reduces carbohydrates levels in developing fruits and woody tissues of Citrus unshiu. Plant Sci., 107, 189-197. http://dx.doi.org/10.1016/0168-9452(95)04111-7

Shimizu, T., Torikara, H., \& Torii, S. (1978). Studiers on the effect of crop load on the composition of Satsuma mandarin trees. V. Analysis of production processes of bearing and non-bearing trees based on the carbohydrate economy. J. Jpn. Soc. Hort. Sci., 46, 465-478

Simanton, W. A. (1970). Seasonal variation in magnitude of foliage growth in Florida citrus groves. Proc. Fla. State Hort. Sci., 48, 49-54

Torikata, H., Hara, M., Torii, S., \& Sakibara, K. (1974). Studies on the effect of crop load on the composition of Satsuma mandarin trees. Diurnal and seasonal fluctuation in osmotic concentration, solute ratio, soluble solids and moisture content in leaves and stems. J. Jpn. Soc. Hort. Sci., 43, 15-23. 